\title{
Antiplatelet Therapy from Clinical Trials to Clinical Practice
}

\author{
Shereif H. Rezkalla, MD, Department of Cardiology, Marshfield Clinic, Marshfield, Wisconsin \\ Michele Benz, Department of Cardiology, Marshfield Clinic, Marshfield, Wisconsin
}

\begin{abstract}
A platelet-rich clot at the site of severe coronary stenosis, plaque erosion, or a recent plaque rupture is the common etiology of acute ischemic syndromes. Thus, antiplatelet therapy is the cornerstone in the management of these conditions. Aspirin in a dose ranging from 160 to $325 \mathrm{mg}$ once daily should be administered to virtually all patients. In patients with severe disease, particularly those who have no acute angiography, clopidogrel (Plavix, Bristol-Myers Squibb/Sanofi Pharmaceuticals) in a dose of $75 \mathrm{mg}$ once daily should add to the benefit of aspirin for up to a year after the event. Clopidogrel also is an alternative to aspirin where a true aspirin allergy exists. Intravenous platelet glycoprotein IIb/Illa receptor inhibitors demonstrated a robust benefit when used in conjunction with coronary intervention and thus far have no role in medical therapy alone. Oral platelet glycoprotein IIb/IIla receptor inhibitors are of no clinical value.
\end{abstract}

\section{INTRODUCTION}

Acute coronary syndromes are a group of closely related diseases that share a common pathophysiologic process. Whether it is a non-ST segment elevation myocardial infarction, a new onset angina, or accelerated angina, plaque rupture is the likely culprit. A platelet-rich clot is formed when platelets interact with the tissue factor, among others, at the site of the plaque. The sudden decrease in lumen size may result in significant ischemia (unstable angina), or even necrosis (non-ST-elevation myocardial infarction). Prevention of platelet aggregation was the focus of investigation in the last few decades, as it may abort the ischemic cascade. The focus of this review is the various drug groups that decrease platelet aggregation, and may have a beneficial role in the treatment of acute coronary syndromes. Specifically, aspirin, thienopyridines and platelet glycoprotein Ilb/Illa receptor inhibitors will be discussed.

REPRINT REQUESTS:

Shereif H. Rezkalla, MD

Department of Cardiology

Marshfield Clinic

1000 North Oak Avenue

Marshfield, WI 54449

Telephone: 715-387-5301

Fax: 715-389-3808

Email: rezkalla.shereif@marshfieldclinic.org

\section{KEYWORDS:}

Aspirin; Plavix; Antiplatelets; Platelet receptors; Coronary intervention 
Asprin

Aspirin therapy has long been recognized as an effective tool in the management of patients with unstable angina. Studies have shown a $40 \%$ reduction in combined events of non-fatal myocardial infarction and death. ${ }^{1}$ The Second International Study of Infarct Survival (ISIS-2), was a randomized trial of IV streptokinase, oral aspirin (160 mg of aspirin a day for one month), both or neither, among 17,187 cases of suspected acute myocardial infarction. ${ }^{2}$ The aspirin group had a $23 \%$ reduction in 5 -week vascular mortality, a hard endpoint. The magnitude of benefit was similar to that of the thrombolytic therapy. The benefit was additive when both drugs were used. The beneficial mortality effect was also apparent on longer follow-up. In that particular study, the aspirin tablet was chewed to provide rapid onset of action. No notable side effects were noted with major bleeds being evenly distributed between the aspirin group and the placebo. More recent studies confirmed the magnitude of aspirin benefits and suggested a time-dependent benefit. ${ }^{3}$ It is thus recommended to use aspirin in various presentations of acute ischemic syndromes in a dose that is at least 160 $\mathrm{mg}$, preferably $324 \mathrm{mg}$, to be given as early as possible in a chewable form. A trial has not been conducted that directly compares the efficacy of different doses of aspirin in the management of acute coronary syndromes.

Aspirin blocks the action of both cyclooxygenase (COX)-1 and COX-2. ${ }^{4}$ Inhibiting COX-1 leads to inhibition of platelet adhesion and aggregation, and aborts the malignant cascade that is triggered by plaque rupture. COX-2 inhibition, with its anti-inflammatory effects, decreases vascular inflammation at the site of the plaque, and that, in turn, reduces mononuclear cell infiltration and enhances plaque stability. 5,6 A recent study by Altman et al. demonstrated that Meloxicam, a preferential COX-2 inhibitor, was associated with a significant reduction in recurrent angina, non-fatal infarction and cardiac death in acute coronary syndromes. ${ }^{7}$ However, anti-inflammatory drugs that act with different mechanisms were of no benefit in treating ischemic syndromes. ${ }^{8-13}$

\section{Thienopyridines}

Ticlopidine (Ticlid, Roche Pharmaceuticals), a thienopyridine derivative, is an antiplatelet agent that blocks platelet activation by affecting ADP-dependent activation of the glycoprotein IIb-IIIa receptor complex. It emerged as an alternative to aspirin in those patients with true aspirin allergy, in patients with aspirin resistance, or in those patients who cannot tolerate aspirin. Its use was limited by an incidence of $2.4 \%$ of severe neutropenia, more frequent occurrence of drug rash, and the recent association with a thrombotic thrombocytic purpura-like syndrome. Clopidogrel (Plavix, Bristol-Myers Squibb/Sanofi Pharmaceuticals) is another thienopyridine derivative that is chemically and pharmacologically related to ticlopidine with a more favorable side effects profile. It is administered as a single daily dose of 75 $\mathrm{mg}$. In the randomized, blinded trial of Clopidogrel vs. Aspirin in Patients at Risk of Ischemic Events (CAPRIE). ${ }^{11}$ Patients were randomized to aspirin (325 $\mathrm{mg}$ once a day) or clopidogrel (75 mg daily). The study population of 19,185 patients had either a recent myocardial infarction, a stroke, or symptomatic peripheral vascular disease. The study population was followed for up to three years. Combined adverse vascular events were $5.32 \%$ in the clopidogrel group versus $5.83 \%$ in the aspirin group, a statistically significant difference in favor of clopidogrel in patients with recurrent incidence of myocardial infarction, a recent stroke and symptomatic peripheral vascular disease. Side effects, including major bleeding and neutropenia, were comparable in both groups. The study proved that clopidogrel is an excellent alternative to aspirin in patients with contraindication to the drug, particularly true aspirin allergy. Would adding clopidogrel to aspirin have an added clinical benefit?

The CURE study (Clopidogrel in Unstable angina to prevent Recurrent ischemic Events) ${ }^{12}$ randomized 12,562 patients with acute coronary syndrome to aspirin alone, or aspirin plus clopidogrel. Combination therapy had less cardiovascular death, non-fatal myocardial infarction and strokes than aspirin alone $(9.3 \%$ vs. $11.4 \%, \mathrm{p}<0.001)$. Combination therapy, however, had more events of major bleeding $(\mathrm{p}<0.001)$.

\section{Lessons learned from the CURE study}

- Adding clopidogrel to aspirin has an added benefit only in high-risk patients with acute coronary syndrome. In the first 3,000 patients the inclusion criterion was chest pain with history of coronary artery disease. The event rates were low, as were the group difference and the rest of the study. Only patients with ischemic electrocardiographic abnormalities or elevated cardiac enzymes were included. In the low-risk population of acute coronary syndrome as the initial diagnosis, adding clopidogrel to aspirin is not routinely recommended.

- In the initial study design, only 9,000 patients were targeted for enrollment. Due to low event rates the enrollment was expanded to 12,500 patients. In the contemporary management of acute coronary syndromes, patients who will have definitive therapies, such as complete revascularization, should not be expected to have a substantial benefit from clopidogrel therapy.

- The main impact of clopidogrel was in preventing myocardial infarctions. There was little benefit as to recurrent and refractory ischemia. The drug should not be looked at as a magic bullet for treatment and control of frequent anginal episodes.

- The benefit of clopidogrel was apparent only a few hours after initiation of therapy. If a decision is made to add clopidogrel, it should be started as soon as possible with a loading dose of $300 \mathrm{mg}$ given orally. Currently, some centers in Europe use 450 to $600 \mathrm{mg}$. However, evidence-based data does not support such a loading dose as being more efficacious than $300 \mathrm{mg}$.

- Excess bleeding did not occur in the subgroup of patients with acute coronary syndrome that had coronary artery bypass surgery. There was no excess bleeding in this subgroup of patients.

$\checkmark$ Patients at high risk of developing bleeding complications should avoid combination therapy. 
- In subgroup analysis, older, female patients benefited less. Further confirmation from large prospective studies is necessary due to the known inherent risk of subgroup analysis.

The percutaneous coronary intervention cure study Two thousand six hundred fifty-eight patients with non-STelevation acute coronary syndrome were assigned to aspirin or aspirin plus clopidogrel, before coronary intervention. ${ }^{13}$ Stented patients had open-label clopidogrel for 4 weeks. Blinded randomization was continued for about 8 months. Clopidogrel patients had less cardiovascular events as compared with aspirin alone. Patients considered for acute intervention will benefit from pre-treatment with clopidogrel combined with aspirin because of the synergistic or added effect. Since intervention mitigates the compromised flow through the diseased coronary artery and since that occurred in both groups of drug assignment, it suggests that the observed benefit is occurring from other coronary variables, but not treated plaques.

\section{Platelet glycoprotein IIb/IIIa receptor inhibitors}

These groups of drugs had been tried in acute coronary syndrome patients undergoing percutaneous coronary intervention, in patients presenting with ST-segment elevation myocardial infarction undergoing primary intervention, and as a primary medical treatment for patients with acute coronary syndromes.

The majority of the studies with this group of drugs were done to investigate their role as adjunctive treatment during percutaneous coronary intervention (table 1). ${ }^{14-21}$ There was a robust benefit noted with all studies and they are recommended in patients undergoing intervention, particularly in high-risk patients.

Two landmark studies have investigated the role of abciximab in primary intervention for acute myocardial infarction. The Controlled Abciximab [ReoPro] and Device
Investigation to Lower Late Angioplasty Complications (CADILLAC) study 22 enrolled 2,082 patients with acute ST-elevation myocardial infarction. Patients were randomized to stenting vs. angioplasty, and to abciximab vs. placebo given in the catheterization laboratory. At 6 months, while there was no difference in death or re-infarction, there was a highly significant difference in the rate of target vessel revascularization. The Abciximab before Direct angioplasty and stenting in Myocardial Infarction Regarding Acute and Long-term follow-up (ADMIRAL) study ${ }^{23}$ went a step farther by administering abciximab or placebo in a mobile intensive care unit, prior to the patient being sent to the catheterization laboratory. Stenting was planned for all patients. With only 300 patients enrolled, a higher rate of coronary potency and improved left ventricular function in the abciximab group was noted. Part of this difference was due to improved coronary flow and higher coronary patency upon arrival to the catheterization laboratory. Whether $\mathrm{IIb} / \mathrm{III}$ inhibitors will add clinical benefit in this group of patients who are managed by thrombolytic therapy is not known, and is currently under intensive investigation.

The benefits derived from these platelet receptor blockers are evident in patients distant to receive definitive treatment with coronary intervention. In the Global Utilization of Streptokinase and Tissue Plasminogen Activator for Occluded Coronary Arteries (GUSTO IV-ACS) study, 24 7,800 acute coronary syndrome patients who were not undergoing early coronary intervention were randomized to abciximab or placebo. There were no clinical benefits seen in the active treatment group.

Oral platelet glycoprotein IIb/IIIa receptor inhibitors Two large-scale studies tested the oral agents, xemilofiban and orbofiban. The studies were generally negative, with only marginal benefit in those patients undergoing coronary intervention (unpublished data). These oral agents are temporarily suspended from further development.

Table 1. Platelet glycoprotein IIb/IIla receptor blockers in acute coronary syndromes.

\begin{tabular}{|c|c|c|c|c|}
\hline Study & Drug* & Population & Number & Results \\
\hline $\mathrm{EPIC}^{14}$ & $\begin{array}{l}\text { abciximab } \\
\text { (ReoPro) }\end{array}$ & $\begin{array}{l}\text { Acute coronary syndrome patients with percutaneous } \\
\text { coronary intervention at high risk for abrupt vessel closure }\end{array}$ & 2,099 & $\begin{array}{l}\text { Less myocardial infarction, } \\
\text { revascularization and mortality }\end{array}$ \\
\hline EPILOG $^{15}$ & $\begin{array}{l}\text { abciximab } \\
\text { (ReoPro) }\end{array}$ & $\begin{array}{l}\text { Acute coronary syndrome patients with percutaneous } \\
\text { coronary intervention-all subsets }\end{array}$ & 2,980 & $\begin{array}{l}\text { Less death, and myocardial } \\
\text { infarction }\end{array}$ \\
\hline CAPTURE 16 & $\begin{array}{l}\text { abciximab } \\
\text { (ReoPro) }\end{array}$ & $\begin{array}{l}\text { Acute coronary syndrome refractory to medical therapy } \\
\text { and planned percutaneous coronary intervention }\end{array}$ & 1,265 & $\begin{array}{l}\text { Less myocardial infarction } \\
\text { before, during and after percu- } \\
\text { taneous coronary intervention }\end{array}$ \\
\hline EPISTENT 17 & $\begin{array}{l}\text { abciximab } \\
\text { (ReoPro) }\end{array}$ & $\begin{array}{l}\text { Acute coronary syndrome undergoing stent or } \\
\text { percutaneous transluminal angioplasty }\end{array}$ & 2,399 & $\begin{array}{l}\text { Improved outcome particularly } \\
\text { in stents }\end{array}$ \\
\hline PURSUIT 18 & $\begin{array}{l}\text { eptifibatide } \\
\text { (Integrilin) }\end{array}$ & $\begin{array}{l}\text { Acute coronary syndrome with ischemic } \\
\text { electrocardiography or elevated cardiac enzymes }\end{array}$ & 10,948 & $\begin{array}{l}\text { Less death or non-fatal } \\
\text { myocardial infarction }\end{array}$ \\
\hline PRISM $^{19}$ & $\begin{array}{l}\text { tirofiban } \\
\text { (Aggrastat) }\end{array}$ & Acute coronary syndrome patients & 3,232 & $\begin{array}{l}\text { Less mortality. No effect on } \\
\text { myocardial infarction }\end{array}$ \\
\hline PRISM-PLUS 20 & $\begin{array}{l}\text { tirofiban } \\
\text { (Aggrastat) }\end{array}$ & $\begin{array}{l}\text { Acute coronary syndrome including non-Q myocardial } \\
\text { infarction with significant symptoms }\end{array}$ & 1,915 & $\begin{array}{l}\text { Lower incidence of ischemic } \\
\text { events }\end{array}$ \\
\hline RESTORE 21 & $\begin{array}{l}\text { tirofiban } \\
\text { (Aggrastat) }\end{array}$ & $\begin{array}{l}\text { Acute coronary syndrome undergoing percutaneous } \\
\text { coronary intervention }\end{array}$ & 2,139 & $\begin{array}{l}\text { Less vascular events early. No } \\
\text { difference at } 30 \text { days }\end{array}$ \\
\hline
\end{tabular}

*ReoPro (Eli Lilly \& Company), Integrilin (COR Therapeutics), Aggrastat (MERCK \& Co. Inc.) 


\section{CONCLUSION}

Antiplatelet therapy plays an important role in the management of acute coronary syndromes. Aspirin should be administered immediately in a dose of 160 to $324 \mathrm{mg}$, in a chewable form. In the case of aspirin allergy, an alternative therapy is clopidogrel in an oral loading dose of $300 \mathrm{mg}$, followed by $75 \mathrm{mg}$ daily.

Adding clopidogrel to aspirin therapy should be considered in high-risk patients, particularly if coronary intervention is not planned. It should be continued for at least 1 month. Longer periods of up to 1 year will also give benefit, however the economic impact of this is still not clear.

Intervenous platelet glycoprotein IIb/IIIa receptor inhibitors have significant impact mainly if used in conjunction with coronary intervention. This is of importance in high-risk patients, particularly in those patients with elevated troponin.

\section{ACKNOWLEDGMENTS}

The authors wish to thank Marshfield Clinic Research Foundation for its support through the assistance of Alice Stargardt and Linda Weis in the preparation of this manuscript.

\section{REFERENCES}

1. Abrams J. Medical therapy of unstable angina and non-Q-wave myocardial infarction. Am J Cardiol 2000;86(suppl):24J-34J.

2. Randomized trial of intravenous streptokinase, oral aspirin, both, or neither among 17,187 cases of suspected acute myocardial infarction: ISIS-2. ISIS-2 (Second International Study of Infarct Survival) Collaborative Group. Lancet 1988;2:349-360.

3. Freimark D, Matetzky S, Leor J, Boyko V, Barbash IM, Behar S, Hod H. Timing of aspirin administration as a determinant of survival of patients with acute myocardial infarction treated with thrombolysis. Am J Cardiol 2002;89:381-385.

4. Verheugt FW, Gersh BJ. Aspirin beyond platelet inhibition. Am J Cardiol 2002;90:39-41.

5 . Verheugt FW. How hot is inflammation in acute coronary syndrome? Eur Heart J 2000;21:1990-1992.

6. Pitt B, Pepine C, Willerson JT. Cyclooxygenase-2 inhibition and cardiovascular events. Circulation 2002;106:167-169.

7. Altman R, Luciardi HL, Muntaner J, Del Rio F, Berman SG, Lopez R, Gonzalez C. Efficacy assessment of meloxicam, a preferential cyclooxygenase- 2 inhibitor, in acute coronary syndromes without ST-segment elevation: the Nonsteroidal Anti-Inflammatory Drugs in Unstable Angina Treatment-2 (NUT-2) pilot study. Circulation 2002;106:191-195.

8. Ray WA, Stein CM, Hall K, Daugherty JR, Griffin MR. Nonsteroidal anti-inflammatory drugs and risk of serious coronary heart disease: an observational cohort study. Lancet 2002;359:118-123.

9. Azar RR, Rinfret S, Theroux P, Stone PH, Dakshinamurthy R, Feng YJ, Wu AH, Range G, Waters DD. A randomized placebo-controlled trial to assess the efficacy of antiinflammatory therapy with methylprednisolone in unstable angina (MUNA trial). Eur Heart J 2000;21:2026-2032

10. Cipollone F, Patrignani P, Greco A, Panara MR, Padovano R, Cuccurullo F, Patrono C, Rebuzzi AG, Liuzzo G, Quaranta G, Maseri A. Differential suppression of thromboxane biosynthesis by indobufen and aspirin in patients with unstable angina. Circulation 1997;96:1109-1116.

11. A randomised, blinded, trial of clopidogrel versus aspirin in patients at risk of ischaemic events (CAPRIE). CAPRIE Steering Committee. Lancet 1996;348:1329-1339.
12. Yusuf S, Zhao F, Mehta SR, Chrolavicius S, Tognoni G, Fox KK; The Clopidogrel in Unstable Angina to Prevent Recurrent Events Trial Investigators. Effects of clopidogrel in addition to aspirin in patients with acute coronary syndromes without ST-segment elevation. N Engl J Med 2001;345:494-502.

13. Mehta SR, Yusuf S, Peters RJ, Bertrand ME, Lewis BS, Natarajan MK, Malmberg K, Rupprecht H, Zhao F, Chrolavicius S, Copland I, Fox KA; Clopidogrel in Unstable angina to prevent Recurrent Events trial (CURE) Investigators. Effects of pretreatment with clopidogrel and aspirin followed by long-term therapy in patients undergoing percutaneous coronary intervention: the PCI-CURE study. Lancet 2001;358:527-533.

14. Moliterno DJ, Califf RM, Aguirre FV, Anderson K, Sigmon KN, Weisman HF, Topol EJ. Effect of platelet glycoprotein IIb/IIIa integrin blockade on activated clotting time during percutaneous transluminal coronary angioplasty or directional atherectomy (the EPIC trial). Evaluation of c7E3 Fab in the Prevention of Ischemic Complications trial. Am J Cardiol 1995;75:559-562.

15. van de Werf F. More evidence for a beneficial effect of platelet glycoprotein IIb/IIIa-blockade during coronary interventions. Latest results from the EPILOG and CAPTURE trials. Eur Heart J 1996; 17:325-326.

16. Randomized placebo-controlled trial of abciximab before and during coronary intervention in refractory unstable angina: the CAPTURE Study. Lancet 1997;349:1429-1435.

17. Randomized placebo-controlled and balloon-angioplasty-controlled trial to assess safety of coronary stenting with use of platelet glycoprotein-IIb/IIIa blockade. The EPISTENT Investigators. Evaluation of Platelet IIb/IIIa Inhibitor for Stenting. Lancet 1998;352:87-92.

18. Inhibition of platelet glycoprotein IIb/IIIa with eptifibatide in patients with acute coronary syndromes. The PURSUIT Trial Investigators. Platelet Glycoprotein IIb/IIIa in Unstable Angina: Receptor Suppression Using Integrilin Therapy. N Engl J Med 1998;339:436-443.

19. A comparison of aspirin plus tirofiban with aspirin plus heparin for unstable angina. Platelet Receptor Inhibition in Ischemic Syndrome Management (PRISM) Study Investigators. N Engl J Med 1998;338:1498-1505.

20. Inhibition of the platelet glycoprotein IIb/IIIa receptor with tirofiban in unstable angina and non-Q-wave myocardial infarction. Platelet Receptor Inhibition in Ischemic Syndrome Management in Patients Limited by Unstable Signs and Symptoms (PRISM-PLUS) Study Investigators. N Engl J Med 1998;338:1488-1497.

21. Effects of platelet glycoprotein IIb/IIIa blockade with tirofiban on adverse cardiac events in patients with unstable angina or acute myocardial infarction undergoing coronary angioplasty. The RESTORE Investigators. Randomized Efficacy Study of Tirofiban for Outcomes and REstenosis. Circulation 1997;96:1445-1453.

22. Stone GW, Grines CL, Cox DA, Garcia E, Tcheng JE, Griffin JJ, Guagliumi G, Stuckey T, Turco M, Carroll JD, Rutherford BD, Lansky AJ; The Controlled Abciximab and Device Investigation to Lower Late Angioplasty Complications (CADILLAC) Investigators. Comparison of angioplasty with stenting, with or without abciximab, in acute myocardial infarction. N Engl J Med 2002;346:957-966.

23. Montalescot G, Barragan P, Wittenberg O, Ecollan P, Elhadad S, Villain P, Boulenc JM, Morice MC, Maillard L, Pansieri M, Choussat R, Pinton P; ADMIRAL Investigators. Abciximab before Direct Angioplasty and Stenting in Myocardial Infarction Regarding Acute and Long-Term Follow-up. Platelet glycoprotein IIb/IIIa inhibition with coronary stenting for acute myocardial infarction. N Engl J Med 2001;344:1895-1903.

24. Simoons ML; GUSTO IV-ACS Investigators. Effect of glycoprotein $\mathrm{IIb} / \mathrm{III}$ a receptor blocker abciximab on outcome in patients with acute coronary syndromes without early coronary revascularisation: the GUSTO IV-ACS randomised trial. Lancet 2001;357:1915-1924. 